\title{
Revisión / Review \\ Resveratrol as an anti-asthmatic agent: could this stilbenoid help against COVID-19 in any way? A meta-analysis
}

\author{
[Resveratrol como agente antiasmático: ¿podría este estilbenoide ayudar contra el COVID-19 de alguna \\ manera? Un metaanálisis]
}

\author{
Ali Parlar ${ }^{1}$, Amner Muñoz-Acevedo ${ }^{2}$, Fatih Üçkardeş ${ }^{3}$, Luisauris Jaimes ${ }^{4}$, Ina Aneva ${ }^{5}$, Bernardo Morales ${ }^{4}$, \\ Amina Unis ${ }^{6,7}$, Maite Rodríguez ${ }^{8}$, Onder Yumrutas ${ }^{1}$, Raúl Vinet ${ }^{9}$, Simona Bungau ${ }^{10}$ \& José L. Martínez ${ }^{11}$ \\ ${ }^{1}$ Department of Pharmacology, Faculty of Medical, University of Adiyaman, Adiyaman, Turkey \\ ${ }^{2}$ Department of Chemistry and Biology, Universidad del Norte, Barranquilla, Colombia \\ ${ }^{3}$ Department of Biostatistics, Faculty of Medicine, Adiyaman University, Adiyaman, Turkey \\ ${ }^{4}$ Department of Biology, Faculty of Chemistry and Biology, Universidad de Santiago de Chile, Santiago, Chile \\ ${ }^{5}$ Institute of Biodiversity and Ecosystem Research, Bulgarian Academy of Sciences, Sofia, Bulgaria \\ ${ }^{6}$ Ras Al Khaimah Medical and Health Sciences University, Ras Al Khaimah, UAE \\ ${ }^{7}$ Faculty of Medicine, University of Alexandria, Egypt \\ ${ }^{8}$ School of Chemistry and Pharmacy, Faculty of Medicine, Andrés Bello University, Santiago, Chile \\ ${ }^{9}$ Laboratory of Pharmacology, Faculty of Pharmacy, Universidad de Valparaíso, Valparaíso, Chile \\ ${ }^{10}$ Department of Pharmacy, Faculty of Medicine and Pharmacy, University of Oradea, Oradea, Romania \\ ${ }^{11}$ Vice Rectory of Investigation, Development and Innovation, Universidad de Santiago de Chile, Santiago, Chile,
}

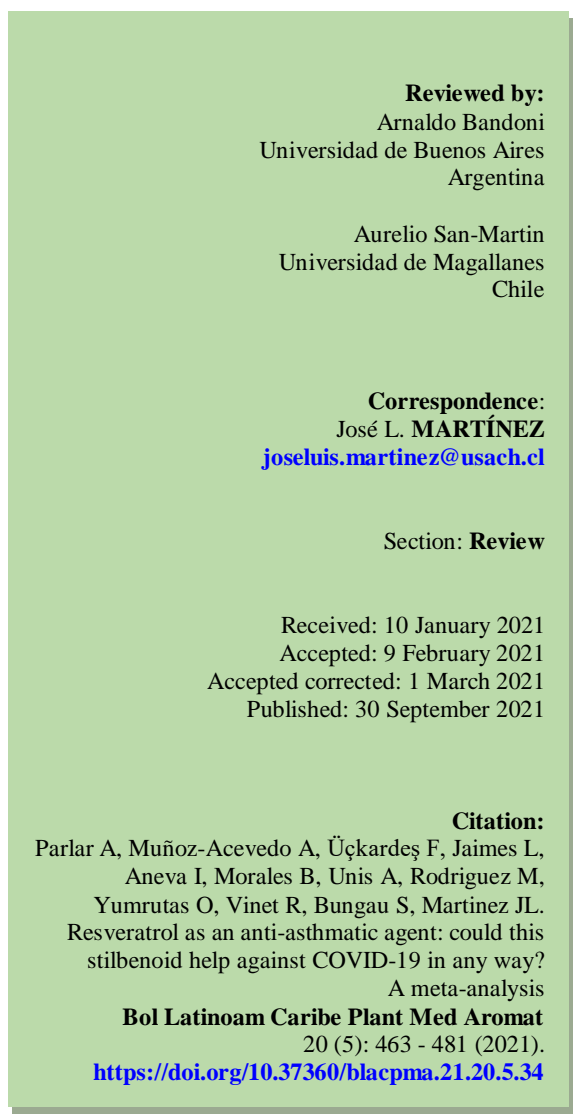

Abstract: Resveratrol is a phenolic phytoconstituent found in many plants. This molecule has always caught the attention of scientists because of biological potentials such as inhibition of inflammation, oxidative stress and platelet aggregation as well as to prevent/protect against cardiovascular and neurodegenerative disease/disorders. Literature search have been conducted over resveratrol in covid-19 and asthma studies published in Pubmed and Google Scholars until 30 September 2020. The criteria used in the literature review were determined and were reviewed works on resveratrol including 368 articles and 47 articles on covid-19 and asthma, respectively. As a result of meta-analysis, TNF- $\alpha$ values of the studies showed a significant difference (heterogeneity) of $\mathrm{I} 2=68.39 \%$ from each other in total (Cohran Q:6.33, $p<0.0423)$. This study shows that resveratrol would have a potential to reduce ARDS symptoms, by suppressing the cytokine storm and severe inflammation caused by SARS-CoV-2, and by showing strong activity against various types of DNA/RNA viruses.

Keywords: Resveratrol; COVID-19; Asthma; Novel coronavirus; Meta analysis.

Resumen: El resveratrol es un fitoconstituyente fenólico que se encuentra en muchas plantas. Esta molécula siempre ha llamado la atención de los científicos debido a sus potenciales biológicos como la inhibición de la inflamación, el estrés oxidativo y la agregación plaquetaria, así como para prevenir/proteger contra enfermedades/trastornos cardiovasculares y neurodegenerativos. Se han realizado búsquedas bibliográficas sobre resveratrol en covid-19 y estudios sobre asma publicados en Pubmed y Google Scholars hasta el 30 de septiembre de 2020. Se determinaron los criterios utilizados en la revisión bibliográfica y se revisaron trabajos sobre resveratrol que incluyen 368 artículos y 47 artículos sobre covid-19 y asma, respectivamente. Como resultado del metanálisis, los valores de TNF- $\alpha$ de los estudios mostraron una diferencia significativa (heterogeneidad) de $\mathrm{I} 2=68,39 \%$ entre sí en total (Cohran Q: 6,33, $p<0,0423)$. Este estudio muestra que el resveratrol podría reducir los síntomas del ARDS al suprimir la tormenta de citocinas y la inflamación severa causada por el SARS-CoV-2, y al mostrar una fuerte actividad contra varios tipos de virus de ADN/ARN.

Palabras clave: Resveratrol; COVID-19; Asma; Nuevo coronavirus; Metanálisis. 


\section{ABBREVIATIONS}

Middle East Respiratory Syndrome Coronavirus MERS-CoV; airway hyperresponsiveness - AHR; interferon- $\gamma$ - IFN- $\gamma$; transforming growth factor beta - TGF- $\beta$; toll-like receptor - TLR; nuclear factor kappa-light-chain-enhancer of activated B cells - NF$\kappa \mathrm{B}$; angiotensin-converting enzyme 2 - ACE2; herpes simplex virus - HSV; early growth response gene product - EGR; long terminal repeat - LTR; human T-cell lymphotrophic virus - HIV; Acute Respiratory Distress Syndrome, ARDS; lipopolysaccharides LPS; house dust mites - HDM; interleukin - IL; immunoglobulin - Ig; malondialdehyde - MDA; myeloperoxidase - MPO; bronchoalveolar lavage fluid - BALF; white blood cells - WBC; tumor necrosis factor alpha - TNF- $\alpha$; nonsteroidal antiinflammatory drugs - NSAID; ovalbumin - OVA.

\section{INTRODUCTION}

Traditional herbal medicines from which mankind has taken benefits since ancient times, remain in force and are increasingly popular despite the advancement and development of modern medicine. One of the reasons for its high acceptability is related to the fact that people are looking for other/new/novel alternatives (environmentally friendly) for the treatment of both physical diseases and psychological disorders, due to the unwanted side effects of some drugs, as well as how affordable and accessible these drugs are (Hodgson, 2015).

Many phytochemicals (e.g., polyphenols) ingested through the diet can act as nutraceuticals, decreasing the risk or preventing the progression of certain diseases including respiratory (e.g., asthma). Among these phytoconstituents, resveratrol, a natural phenolic stilbene $\left(\mathrm{C}_{6}-\mathrm{C}_{2}-\mathrm{C}_{6}\right.$ scaffold $)$, found in many fruits such as grapes, peanuts (Chang et al., 2006), blackcurrant, raspberry, cranberry, chokeberry, blackberry (Lin et al., 2017; Kim, 2018) and vegetables (Martinez et al., 2020), plays an important role as a therapeutic and chemopreventive agent in the treatment of various diseases; it was first isolated from Veratrum grandiflorum in 1940, and later it was also identified in a traditional Japanese and Chinese medicine called Ko-jo-kon (Polygonum cuspidatum) (Takaoka, 1940).

Although many modern medications (e.g., anticholinergics, $\beta$-adrenergic agonists, steroids, antihistamines, antileukotrienes, and phosphordiesterase inhibitors) through direct therapy are used to treat asthma to date, a significant number of patients experience repeated asthmatic attacks
(Janssen \& Killian, 2006). In addition, long-term and excessive use of some of these drugs, especially nonsteroidal anti-inflammatory drugs (NSAID) and corticosteroids, can cause undesirable side effects such as gastrointestinal toxicity, addiction, drug resistance, and induction of Cushing's syndrome (Hodgson, 2015), which would limit the use of current therapies in related patients, and accordingly, new therapeutic agents are needed that target both inflammation and pathways of airway smooth muscle contraction (Fanta, 2009; Lam et al., 2018). In this sense, use of active ingredients (e.g., shikimic acid) from plants (Illicum verum, I. religiosum - star anise) to obtain intermediates/pro-drugs/drugs (oseltamivir Tamiflu $^{\circledR}$ ) for the treatment of respiratory diseases (e.g., H1N1 influenza, avian flu, influenza types A/B) (Alhajj et al., 2020; Singh et al., 2020) has become a valuable alternative for pharmaceutical companies, due to both its high effectiveness and relatively few side effects.

Since the first outbreak reported in the Chinese city of Wuhan in December 2019, the world has witnessed the pandemic spread of the recently identified SARS-CoV-2 (severe acute respiratory syndrome coronavirus 2 , related to a $\beta$-coronavirus), which is responsible for coronavirus disease 2019 (COVID-19) (Fei et al., 2020; Lu et al., 2020; Zhu et $a l ., 2020$ ), and since early 2020, it has broadcast rapidly in Europe first and later in America to date, causing approximately 400 thousand deaths and 6.5 million infections, according to reports (June 2020) from Johns Hopkins University and the European Centre for Disease Prevention and Control (Thiery, 2020). The new coronavirus pandemic is a major challenge to health systems worldwide, with 144.5 million people infected and almost 3.100.000 deaths (as of April 21, 2021) (Worldometer, 2021). The most common mode of SARS-CoV-2 transmission is from human to human through respiratory droplets or direct contact, having an average incubation period of 5.1 days and an estimated basic reproduction number of 2.24-3.58 per each infected individual (Jackowska et al., 2020; Rajwa et al., 2020).

On the other hand, referring to asthma as a respiratory disorder, this is a chronic inflammatory disease that affects more than 300 million people in the world and its prevalence has continuously increased; children are the group with the highest percentage of the disease compared to the other age groups (Kudo et al., 2013). Asthma is characterized by airway inflammation, hyper responsiveness, and reversible airflow obstruction (D'Amato et al., 2016); 
it also produces symptoms of chest tightness, wheezing, and cough (Zhai et al., 2018). The pathogenesis of asthma is very complex due to various factors such as cytokines (e.g., interleukins, chemokines), growth factors, reactive oxygen species, inflammatory and $\mathrm{T}$ cells (e.g, eosinophils, lymphocytes, neutrophils) (Pelaia et al., 2008).

\section{MATERIAL AND METHODS}

This meta-analysis, Systematic Reviews, was conducted on the model of the Preferred Reporting Elements for Meta-Analyzes (PRISMA) statement by Liberati et al. (2009).

\section{Search strategy}

The words "Resveratrol", "Sars", "Asthma" and "Covid-19" were searched separately in Scopus, MEDLINE/Pubmed and Google Scholar (Up to September 10, 2020). The research was limited to English-language, human and animal studies, and reviews, including clinical studies only. The "criteria for inclusion" included randomized, controlled trials comparing only different interventions with key words. If other interventions were given, it was considered that they should be the same in all treatment groups. Also, only articles published in peer-reviewed journals Iran $\mathbf{J}$ Pharm Res. Chin J Pharmaceut Anal Med Plant Commun and some others were included in this study. Since covid-19 is so new, the resveratrol literature search was conducted independently of covid-19, while a literature search was performed together with asthmacovid19 and asthma-resveratrol. see fonts The reference list was designed using the "Mendeley" program.

\section{Data extraction}

All articles to be accepted as reference were reviewed by all authors. Articles for which double-blind peerreview was not evaluated were excluded. Extracted data included information about the study design, characteristics, amount of resveratrol, other compounds, the ratio of resveratrol to other compounds. For meta-analysis, articles measuring the level of TNF- $\alpha$ were searched.

\section{Statistical analysis}

Data tables were created after all the combined literature was carefully read and the data were extracted according to the requirements of the metaanalysis. Further analysis GraphPad Prism 7.01 (San Diego, CA 92108) was used and $p$ values less than
0.05 were considered significant.

Meta-analysis was performed using Medcalc 19.5.3. MedCalc uses the Hedges g statistic as a formulation for the standardized mean difference under the fixed effects model. Next the heterogeneity statistic is incorporated to calculate the summary standardized mean difference under the random effects model.

\section{RESULTS}

As a result of the literature search about "resveratrol" as described above, 13,571 and 37,000 articles were found in pubmed and google scholar respectively. Moreover, as a result of the search for the keywords "asthma" together with "resveratrol" in the same databases, 47 and 17,700 articles were found respectively. The keyword "covid-19" reached 58,155 and 1,320,000 results, respectively. However, as a result of searching these three main words together, no articles were found. As illustrated in Figure No. 1, only 47 studies were found to investigate the relationship between resveratrol and asthma patients' outcomes.

In the articles related to asthma and resveratrol, 5 articles examining the level of TNFalpha were reviewed. Accordingly, the statistical data of the test are given in Figure No. 2.

As a result of the meta-analysis, it was found that the heterogeneity of the TNF- $\alpha$ values of the studies was significant (Cochran Q: 6.33, $p<0.0423$ ) and the degree of heterogeneity was $\mathrm{I} 2=68.39 \%$. The results of these studies differ from each other by a total of $68.39 \%$.

The phenol resveratrol (3,4',5-trihydroxytrans-stilbene, 5-[(1E)-2-(4-hydroxyphenyl) ethenyl]1,3-benzenediol - Figure No. 3a) is a phytoalexin biosynthesized in plant sources against causingdisease or damage/stress agents; this molecule occurs in two isomeric forms ( $\mathrm{E}$ and $\mathrm{Z}$ ) along with its glycosylated derivatives [E-/Z-piceid (E-/Zresveratrol-3-O- $\beta$-D-glucopyranoside) - Figure No. $3 \mathrm{~b}$ ] and it is also a powerful antioxidant. Many studies have been conducted/documented in cell and animal trials on resveratrol and its ability to prevent cardiovascular diseases (Jang et al., 1997; Sahebkar et al., 2015) and cancer (Carbó et al., 1999; Parlar \& Arslan, 2019), along with its potential to reduce inflammation (Guzman et al., 2018), inhibit high glucose-induced cell damage (Hu et al., 2016), inhibit antioxidant capacity (Guzman et al., 2018; Muñoz et al., 2020), inhibit the oxidation of low-density lipoproteins, inhibit platelet aggregation (Frémont $e t$ 
al., 1999), protect against neurodegenerative disorders (Pourhanifeh et al., 2019), decreasing cardiometabolic risk factors (Stivala et al., 2001) and even prolong life (McMichael et al., 2020).

Covid-19 is the most serious disease that has affected the planet almost completely (Guo et al., 2017), and it is well known that all coronaviruses affect the respiratory system; nevertheless, SARSCoV-2 adheres more efficiently to the lower airways

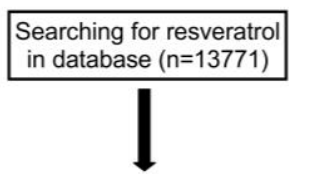

Articles on resveratrol related to asthma $(n=47)$

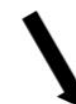

Searching for covid-19 and asthma

in database $(n=368)$

Searching for resveratrol and asthma in database $(n=47)$

Figure No. 1

Article selection process

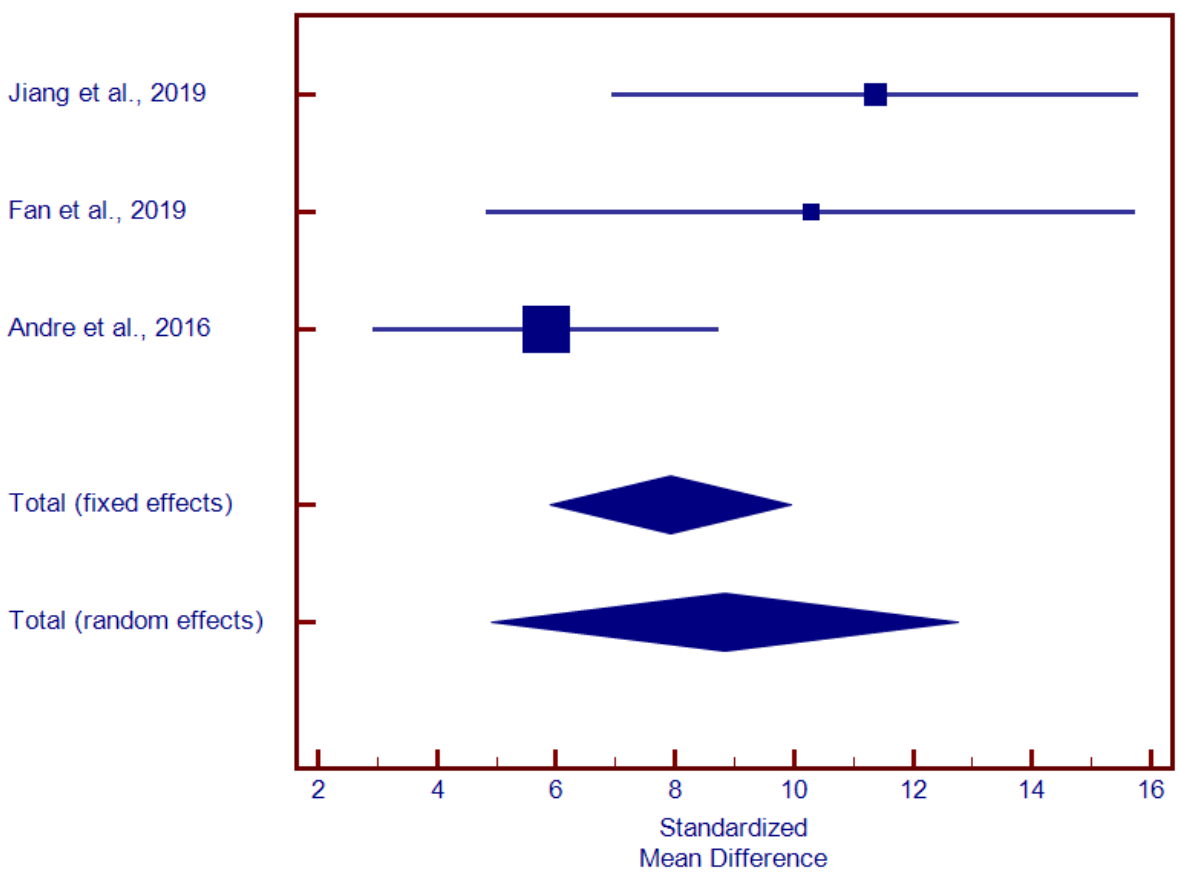

Figure No. 2

Meta-analyses of three case-control studies relating TNF alpha. Summary compare means calculated by random and fixed effects method. Heterogeneity: Q:6,33, $p<0.0423, \mathrm{I2}=68,39 \%, 95 \%$ CI for $=0,00$ to 90,82

(André et al., 2016; Fan et al., 2019; Jiang et al., 2019)

Boletín Latinoamericano y del Caribe de Plantas Medicinales y Aromáticas / 466 
<smiles>Oc1ccc(/C=C/c2cc(O)cc(O)c2)cc1</smiles>

$E$-Resveratrol<smiles>OC[C@H]1O[C@@H](Oc2cc(O)cc(C=Cc3ccc(O)cc3)c2)[C@H](O)[C@@H](O)[C@@H]1O</smiles>

E/Z-Piceid

Figure No. 3

$E$-Resveratrol; $E / Z$-Piceid

This new pandemic is a great challenge for health systems worldwide (Worldometer, 2020). In all countries, the treatment of patients affected by COVID-19 has been prioritized, and all resources have been focused on finding and/or expanding more clinical resources to serve the population where the increase in Covid-19 cases seems to go hand in hand with falling temperatures. Ways to prevent and/or delay the progress of infections have been established/assumed differently by each country. In this way, local decrees have arisen in the countries themselves as well as other more specialized documents for large groups (Cunningham et al., 2020).

While big pharmaceutical companies/laboratories around the world are searching for new drugs that can directly or indirectly combat Covid-19, comorbidities such as hypertension, diabetes and respiratory disorders (such as asthma), among others, in patients with Covid-19 would rapidly increase their critical states to impending doom (Tian \& Liu, 2020).

The purpose of this review is to report how the phytoconstituent resveratrol has been effective against asthma and thus, hypothetically it could have an impact on the decrease of comorbidity (asthma) in patients with Covid-19 and therefore, an improvement in life expectancy of critically ill patients. The manuscript will mention the effect of resveratrol and its mechanism of action on asthma.

\section{Plants containing resveratrol}

Some plants containing resveratrol are included in Table No. 1. Thus, 111 species belonging to 71 genera and 34 families have been included in this Table No. 1. 
Table No. 1

\begin{tabular}{|c|c|c|c|c|c|}
\hline Study & $\begin{array}{c}\text { Research } \\
\text { type }\end{array}$ & $\begin{array}{c}\text { measurement } \\
\text { method }\end{array}$ & $\begin{array}{c}\text { Quantification of } \\
\text { resveratrol }\end{array}$ & Family & Species \\
\hline Tian \& Liu, 2020 & Review & -- & -- & & $\begin{array}{l}\text { Alnus spp., Aster } \\
\text { tataricus L. f., } \\
\text { Syneilesis } \\
\text { aconitifolia (Bge.) } \\
\text { Maxim, Vaccinium } \\
\text { dendrocharis Hand. } \\
\text {-Mazz., Vaccinium } \\
\text { chaetothrix Sleumer, } \\
\text { Vaccinium } \\
\text { moupinense Franch., } \\
\text { Vaccinium } \\
\text { sikkimense C. B. } \\
\text { Clarke, Euphorbia } \\
\text { humifusa Willd. ex } \\
\text { Schlecht., Poa } \\
\text { annua L, Festuca } \\
\text { ovina L. Stipa } \\
\text { tianschanica } \\
\text { (Roshev.) Norl, } \\
\text { Stipa tianschanica } \\
\text { (Roshev.) Norl }\end{array}$ \\
\hline Da Silva et al., 2014 & $\begin{array}{l}\text { Chemical } \\
\text { research }\end{array}$ & $\begin{array}{l}\text { Chemical } \\
\text { analysis }\end{array}$ & $0.56 \times 10^{-2} \mathrm{ng} / \mathrm{mL}$ & Bromeliaceae & $\begin{array}{l}\text { Ananas comosus }(\mathrm{L}) \\
\text { Merr. }\end{array}$ \\
\hline Suzuki et al., 1987 & $\begin{array}{l}\text { Chemical } \\
\text { research }\end{array}$ & $\begin{array}{l}\text { Spectroscopic } \\
\text { analysis }\end{array}$ & -- & Cyperaceae & $\begin{array}{l}\text { Carex fedia var. } \\
\text { miyabei (Franchet) } \\
\text { T. Koyama }\end{array}$ \\
\hline Ito et al., 2003 & $\begin{array}{l}\text { Chemical } \\
\text { research }\end{array}$ & $\begin{array}{l}\text { Spectroscopic } \\
\text { analysis }\end{array}$ & -- & Dipterocarpaceae & $\begin{array}{l}\text { Vatica pauciflora } \\
\text { (Korth.) Bl. }\end{array}$ \\
\hline Lyons et al., 2003 & $\begin{array}{l}\text { Chemical } \\
\text { research }\end{array}$ & LC-MS/MS & $36 \mathrm{ng} / \mathrm{g}$ & Ericaceae & $\begin{array}{l}\text { Vaccinium myrtillus } \\
\text { Linn. }\end{array}$ \\
\hline $\begin{array}{c}\text { Rimando \& Barney, } \\
2005\end{array}$ & $\begin{array}{l}\text { Chemical } \\
\text { research }\end{array}$ & GC/MS & $0.26-4.67 \mu \mathrm{g} / \mathrm{g}$ & Ericaceae & $\begin{array}{l}\text { Vaccinium } \\
\text { haitangense Sleumer }\end{array}$ \\
\hline $\begin{array}{c}\text { Borowska et al., } \\
2009\end{array}$ & $\begin{array}{l}\text { Chemical } \\
\text { research }\end{array}$ & HPLC & $712.3 \mathrm{ng} / \mathrm{g}$ & Ericaceae & $\begin{array}{l}\text { Vaccinium } \\
\text { microcarpum } \\
\text { (Turcz. ex Rupr.) } \\
\text { Schmalh. }\end{array}$ \\
\hline $\begin{array}{c}\text { Česoniene \& } \\
\text { Daubaras, } 2015\end{array}$ & $\begin{array}{l}\text { Chemical } \\
\text { research }\end{array}$ & HPLC & $533.4 \mathrm{ng} / \mathrm{g}$ & Ericaceae & $\begin{array}{l}\text { Vaccinium } \\
\text { oxycoccos Linn. }\end{array}$ \\
\hline Tanaka et al., 2001 & $\begin{array}{l}\text { Chemical } \\
\text { research }\end{array}$ & $\begin{array}{l}\text { Spectroscopic } \\
\text { analysis }\end{array}$ & $429.6 \mathrm{ng} / \mathrm{g}$ & Gnetaceae & $\begin{array}{l}\text { Gnetum parvifolium } \\
\text { (Warb.) C. Y. Cheng } \\
\text { ex Chun }\end{array}$ \\
\hline Xiang et al., 2002 & $\begin{array}{l}\text { Chemical } \\
\text { research }\end{array}$ & chromatography & $16.3 \mathrm{ng} / \mathrm{g}$ & Gnetaceae & $\begin{array}{l}\text { Gnetum montanum } \\
\text { Markgr }\end{array}$ \\
\hline Huang et al., 2000 & $\begin{array}{l}\text { Chemical } \\
\text { research }\end{array}$ & UV spectra & $161.7 \mathrm{ng} / \mathrm{g}$ & Gnetaceae & $\begin{array}{l}\text { Gnetum hainanense } \\
\text { C. Y. Cheng }\end{array}$ \\
\hline Powell et al., 1994 & $\begin{array}{l}\text { Chemical } \\
\text { research }\end{array}$ & GC/MS & $2300 \mathrm{ppm}$ & Poaceae & Lolium perenne L. \\
\hline
\end{tabular}




\begin{tabular}{|c|c|c|c|c|c|}
\hline Ehala et al., 2005 & $\begin{array}{l}\text { Chemical } \\
\text { research }\end{array}$ & $\begin{array}{l}\text { capillary zone } \\
\text { electrophoresis }\end{array}$ & $97.8 \%$ & Grossulariaceae & Ribes nigrum $\mathrm{L}$. \\
\hline $\begin{array}{l}\text { Muangthai \& } \\
\text { Sutiono, } 2014\end{array}$ & $\begin{array}{l}\text { Chemical } \\
\text { research }\end{array}$ & HPLC & $76.82 \mathrm{~g} / \mathrm{L}$ & Lauraceae & Cinamomum spp. \\
\hline $\begin{array}{c}\text { Irnidayanti et al., } \\
2019\end{array}$ & $\begin{array}{l}\text { Chemical } \\
\text { research }\end{array}$ & TLC, HPLC & $65.15-55.35 \%$ & Fabaceae & $\begin{array}{l}\text { Glycine max (Linn.) } \\
\text { Merr. }\end{array}$ \\
\hline $\begin{array}{c}\text { Anjaneyulu et al., } \\
1984\end{array}$ & $\begin{array}{l}\text { Chemical } \\
\text { research }\end{array}$ & X-rays & $6.79-2 \mathrm{H}, \mathrm{d}, \mathrm{J}=8 \mathrm{~Hz}$ & & $\begin{array}{l}\text { Bauhinia racemosa } \\
\text { Lam. }\end{array}$ \\
\hline $\begin{array}{l}\text { Chukwumah et al., } \\
2009\end{array}$ & $\begin{array}{l}\text { Chemical } \\
\text { research }\end{array}$ & HPLC & $9.49 \mathrm{mg} / \mathrm{mL}$ & & $\begin{array}{l}\text { Arachis hypogaea } \\
\text { Linn. }\end{array}$ \\
\hline Liu et al., 2004 & $\begin{array}{l}\text { Chemical } \\
\text { research }\end{array}$ & $\mathrm{X}$-rays & $\begin{array}{l}6.33(1 \mathrm{H}, \mathrm{d}, \mathrm{J} 2.5 \\
\mathrm{Hz}) \text { this is not a } \\
\text { quantification! }\end{array}$ & & $\begin{array}{l}\text { Caragana } \\
\text { stenophylla Pojark. }\end{array}$ \\
\hline Kineman et al., 2010 & $\begin{array}{l}\text { Chemical } \\
\text { research }\end{array}$ & HPLC & $\begin{array}{l}0.1 \pm 0.08 \mathrm{nmol} / \mathrm{g} \\
\text { tissue }\end{array}$ & & Medicago sativa L. \\
\hline Tian et al., 2008 & $\begin{array}{l}\text { Chemical } \\
\text { research }\end{array}$ & X-rays & $\begin{array}{l}7.46(\mathrm{dd}, \mathrm{J} 1 / 46.5, \\
2.0 \mathrm{~Hz}, 2 \mathrm{H})\end{array}$ & & $\begin{array}{l}\text { Ammopiptanthus } \\
\text { mongolicus (Maxim. } \\
\text { ex Kom.) Cheng f. }\end{array}$ \\
\hline Ning et al., 2013 & $\begin{array}{l}\text { Chemical } \\
\text { research }\end{array}$ & HPLC & $62.89 \mathrm{~g} / \mathrm{L}$ & & $\begin{array}{l}\text { Vigna umbellata } \\
\text { (Thunb.) Ohwi et } \\
\text { Ohashi }\end{array}$ \\
\hline Takaoka, 1940 & Review & -- & -- & & $\begin{array}{l}\text { Veratrum } \\
\text { grandiflorum } \\
\text { (Maxim.) Loes. } f\end{array}$ \\
\hline Zhao et al., 1998 & Review & -- & -- & & $\begin{array}{l}\text { Veratrum nigrum } \mathrm{L} \text {. } \\
\text { var. ussuriense } \\
\text { Nakai }\end{array}$ \\
\hline Zhou et al., 1999 & $\begin{array}{l}\text { Chemical } \\
\text { research }\end{array}$ & Enzyme assay & $30 \mu \mathrm{M}$ & & $\begin{array}{l}\text { Veratrum taliense } \\
\text { Loes. } f .\end{array}$ \\
\hline Wu et al., 2018 & $\begin{array}{l}\text { Chemical } \\
\text { research }\end{array}$ & HPLC & $0.478 \mathrm{mg} / \mathrm{g}$ & & $\begin{array}{l}\text { Veratrum maackii } \\
\text { Regel }\end{array}$ \\
\hline Yuan et al., 2018 & $\begin{array}{l}\text { Chemical } \\
\text { research }\end{array}$ & HPLC & $0.549 \mathrm{mg} / \mathrm{g}$ & & $\begin{array}{l}\text { Ornithogalum } \\
\text { caudatum Jacq }\end{array}$ \\
\hline Wang et al., 2013 & Abstract & Chromatography & & & $\begin{array}{l}\text { Smilax scobinicaulis } \\
\text { C. H. Wright }\end{array}$ \\
\hline Li et al., 2007 & $\begin{array}{l}\text { Chemical } \\
\text { research }\end{array}$ & HPLC & $0.288 \mathrm{mg} / \mathrm{mL}$ & & Smilax glabra Roxb \\
\hline Shu et al., 2002 & $\begin{array}{l}\text { Chemical } \\
\text { structure }\end{array}$ & $\begin{array}{l}\text { Ultraviolet } \\
\text { spectra }\end{array}$ & $7.65, \mathrm{~d}, \mathrm{~J}=15.9 \mathrm{~Hz}$ & & $\begin{array}{l}\text { Smilax bracteata } \\
\text { Presl }\end{array}$ \\
\hline Sagar et al., 2006 & $\begin{array}{l}\text { Chemical } \\
\text { research }\end{array}$ & HPLC & $20 \%$ & Magnoliaceae & $\begin{array}{l}\text { Magnolia officinalis } \\
\text { Rehd. et Wils. }\end{array}$ \\
\hline Xu et al., 2004 & $\begin{array}{l}\text { Chemical } \\
\text { structure }\end{array}$ & $\begin{array}{l}\text { Ultraviolet } \\
\text { spectra }\end{array}$ & $\begin{array}{l}1 \mathrm{H}, \mathrm{d}, \mathrm{J}=1.5 \mathrm{~Hz}, \\
\mathrm{H}-6\end{array}$ & Myrcinaceae & $\begin{array}{l}\text { Aegiceras } \\
\text { corniculatum (Linn.) } \\
\text { Blanco }\end{array}$ \\
\hline $\begin{array}{c}\text { Rajkumari et al., } \\
2018\end{array}$ & $\begin{array}{l}\text { Animal } \\
\text { research }\end{array}$ & $\begin{array}{l}\text { Anti-oxidant } \\
\text { activity }\end{array}$ & $8000 \mathrm{IU}$ & & $\begin{array}{l}\text { Syzygium jambos } \\
\text { (L.) Alston }\end{array}$ \\
\hline Hillis \& Inoue, 1967 & $\begin{array}{l}\text { Chemical } \\
\text { structure }\end{array}$ & HPLC & $62.1 \%$ & Nothofagaceae & $\begin{array}{l}\text { Nothofagus fusca } \\
\text { Hook.f. }\end{array}$ \\
\hline Li et al., 2009 & $\begin{array}{l}\text { Chemical } \\
\text { structure }\end{array}$ & $\mathrm{MS} / \mathrm{MS}$ & $0.529 .6 \mathrm{mg} / \mathrm{g}$ & & Pinus sylvestris L. \\
\hline
\end{tabular}




\begin{tabular}{|c|c|c|c|c|c|}
\hline Lee et al., 2016 & $\begin{array}{l}\text { Chemical } \\
\text { structure }\end{array}$ & HPLC & $0.322 \mathrm{mg} / \mathrm{mL}$ & & $\begin{array}{l}\text { Pinus koraiensis } \\
\text { Sieb. et Zucc. }\end{array}$ \\
\hline Aritomi et al., 1965 & $\begin{array}{l}\text { Chemical } \\
\text { research }\end{array}$ & UV spectra & -- & & $\begin{array}{l}\text { Rumex japonicus } \\
\text { Houtt. }\end{array}$ \\
\hline Kim et al., 2002 & $\begin{array}{l}\text { Chemical } \\
\text { research }\end{array}$ & HPLC & $59 \mathrm{mg} / 0.18 \mathrm{~g}$ & Ranunculaceae & $\begin{array}{l}\text { Paeonia suffruticosa } \\
\text { Andr. }\end{array}$ \\
\hline Sarker et al., 1999 & $\begin{array}{l}\text { Chemical } \\
\text { research }\end{array}$ & HPLC & $\begin{array}{l}\mathrm{ED}_{50}=10 \text { to } 50 \\
\mu \mathrm{M} v s . \\
5 \times 10^{-8} \mathrm{M} 20- \\
\text { hydroxyecdysone) }\end{array}$ & & $\begin{array}{l}\text { Paeonia suffruticosa } \\
\text { (Andr.) Kerner }\end{array}$ \\
\hline Yu et al., 2019 & Review & & -- & Rosaceae & Rubus chingii $\mathrm{Hu}$ \\
\hline Gadani et al., 2017 & $\begin{array}{l}\text { Animal } \\
\text { research }\end{array}$ & $\begin{array}{l}\text { Antioxidants } \\
\text { activity }\end{array}$ & $\begin{array}{l}51.0 \pm 7.6 \text { vs } 29.6 \\
\pm 11.3 \mu \mathrm{M}\end{array}$ & Theaceae & $\begin{array}{l}\text { Camellia sinensis } \\
\text { (L.) Kuntze }\end{array}$ \\
\hline Soural et al., 2015 & $\begin{array}{l}\text { Chemical } \\
\text { research }\end{array}$ & LC/MS & $6030 \pm 680 \mu \mathrm{g} / \mathrm{g}$ & Vitaceae & Vitis vinifera $\mathrm{L}$. \\
\hline Ji et al., 2014 & $\begin{array}{l}\text { Chemical } \\
\text { research }\end{array}$ & HPLC & $0.009 \mu \mathrm{g} / \mathrm{mL}$ & & $\begin{array}{l}\text { Vitis amurensis } \\
\text { Rupr. }\end{array}$ \\
\hline Kim et al., 2007 & $\begin{array}{l}\text { Chemical } \\
\text { research }\end{array}$ & HPLC & $5.2 \mathrm{mg} / 500 \mathrm{mg}$ & & $\begin{array}{l}\text { Ampelopsis japonica } \\
\text { (Thunb.) Makino }\end{array}$ \\
\hline $\begin{array}{c}\text { Adesanya et al., } \\
1999\end{array}$ & $\begin{array}{l}\text { Chemical } \\
\text { structure }\end{array}$ & $\begin{array}{l}\text { UV spectra it is } \\
\text { impossible } \\
\text { identify only by } \\
\text { UV! }\end{array}$ & $\begin{array}{l}6.21,2 \mathrm{H}, \mathrm{d}, \mathrm{J}=2 \\
\mathrm{~Hz}\end{array}$ & & $\begin{array}{l}\text { Cissus } \\
\text { quadrangularis L. }\end{array}$ \\
\hline Lins et al., 1991 & $\begin{array}{l}\text { Chemical } \\
\text { structure }\end{array}$ & UV spectra & $\begin{array}{l}7.30,3 \mathrm{H}, \mathrm{d}, \mathrm{J}=8.5 \\
\mathrm{~Hz}\end{array}$ & & $\begin{array}{l}\text { Parthenocissus } \\
\text { tricuspidata (S. et } \\
\text { Z.) Planch. }\end{array}$ \\
\hline Tanaka et al., 1998 & $\begin{array}{l}\text { Chemical } \\
\text { structure }\end{array}$ & UV spectra & $1 \mathrm{H}, \mathrm{d}, \mathrm{J}=2.0 \mathrm{~Hz}$ & & $\begin{array}{l}\text { Parthenocissus } \\
\text { quinquefolia (L.) } \\
\text { Planch. }\end{array}$ \\
\hline Syah et al., 2000 & $\begin{array}{l}\text { Chemical } \\
\text { structure }\end{array}$ & UV spectra & $\begin{array}{l}7.231 \mathrm{H}, \mathrm{d}, \mathrm{J}=16.4 \\
\mathrm{~Hz}\end{array}$ & & $\begin{array}{l}\text { Morus macroura } \\
\text { Miq. }\end{array}$ \\
\hline Choi et al., 2013 & $\begin{array}{l}\text { Chemical } \\
\text { research }\end{array}$ & $\begin{array}{l}\text { NMR spectral } \\
\text { analysis }\end{array}$ & $\begin{array}{l}23.7 \text { to } 105.5 \mathrm{mg} \\
\% \text { in six different } \\
\text { mulberry cultivars. }\end{array}$ & & Morus alba L. \\
\hline Abbas et al., 2014 & $\begin{array}{l}\text { Chemical } \\
\text { structure }\end{array}$ & $\begin{array}{l}\text { NMR spectral } \\
\text { analysis }\end{array}$ & $2 \mathrm{H}, \mathrm{d}, \mathrm{J}=2.0 \mathrm{~Hz}$ & & Morus nigra L. \\
\hline Chen et al., 2015 & & CD spectra & $\begin{array}{l}6.30(1 \mathrm{H}, \mathrm{dd}, \\
\mathrm{J}=8.0,2.0 \mathrm{~Hz}, \mathrm{H}-8\end{array}$ & & $\begin{array}{l}\text { Cudrania } \\
\text { cochinchinensis } \\
\text { Lour. }\end{array}$ \\
\hline Borah et al., 2017 & & $\begin{array}{l}\text { Ultraviolet- } \\
\text { visible }\end{array}$ & $85.00 \mathrm{mg} / \mathrm{kg}$ & & $\begin{array}{l}\text { Artocarpus lakoocha } \\
\text { Roxb. }\end{array}$ \\
\hline
\end{tabular}




\section{Asthma}

Asthma is a reversible airway obstruction that increases sensitivity in the lungs, mucus production, and inflammation in the airway (James et al., 2009). It includes pathophysiological condition, epithelial fibrosis, metaplasia and hyperplasia of goblet cells, hypersecretion of mucus (Shinagawa \& Kojima, 2003). Asthma is a disease with different phenotypes but does not have a standard way of defining them (Wenzel, 2006), and to determine them not only are the clinical parameters sufficient, but other biomarkers are also needed to find genetic/phenotypic differences (Hesselmar et al., 2012). In establishing the specific phenotypes of asthma, several particular models of asthma have been suggested and demonstrated in animal models.

\section{DISCUSSION}

This work is a review that seeks to correlate the therapeutic effects of resveratrol and certain plants containing it against some respiratory diseases such as ARDS and asthma, which are caused by many pathogens, including SARS-CoV-2, as well as provides information to researchers in these areas.

Isolation of viruses from the upper airway of asthmatic patients during clinical exacerbations suggested that viruses may play an important role in asthma (Johnston et al., 1995), and therefore, they are common triggers for these exacerbations (Kumar et al., 2020). In most people with asthma, Th2 mediators increase, as well as when a viral infection arises (Contoli et al., 2006); such Th2 mediators like IL-4 and IL-13 can inhibit epithelial production of type I interferon (Contoli et al., 2015). Furthermore, interferon $\alpha$ can suppress the polarization of Th2 cells in $\mathrm{T}$ cells and, consequently, can attenuate the expression of GATA3, IL-4 and IL-5 (Huber et al., 2010; Pritchard et al., 2012). Evidence for this is that type 2 inflammation occurs in mice with type I IFN receptor deficiency in response to pulmonary eosinophilia and influenza infection in mice (Duerr et al., 2016). Additionally, the results of a series of previous in vitro and in vivo studies in humans and animals for various asthma-related viruses, e.g., rhinovirus, influenza, and respiratory syncytial virus, promote this hypothesis (Chen et al., 2019; Han et al., 2019; Lee et al., 2019).

Previous studies on T-cell lymphotrophic virus 1 (HIV-1) showed that resveratrol led to the activation of the lytic cycle of HIV-1, attenuation of the HIV-1 Tat-induced long terminal repeat (LTR) transactivation and inhibition of HIV-1 replication when used synergistically with nucleoside analogues by activating the early growth response gene product 1 (EGR-1) and sirtuin 1 and prolonging the S-phase of the cell cycle, respectively (Heredia et al., 2000; Krishnan \& Zeichner, 2004; Wang et al., 2004; Zhang et al., 2009). In addition, Faith et al. (2006) and Docherty et al. (2006) demonstrated that resveratrol, by suppressing activation of the NF- $\kappa \mathrm{B}$ pathway, inhibited the replication of varicella-zoster virus (VZV) and herpes simplex virus 1 and 2 (HSV1 and HSV-2). Similarly, Palamara et al. (2005), established (both in vivo and in vitro assays) that resveratrol inhibited the replication of influenza A virus by causing inhibition of protein kinase $\mathrm{C}$ activity.

SARS-CoV-2 binds to respiratory epithelial cells via angiotensin-converting enzyme 2 (ACE2) (Kim et al., 2020) and the virus links to the host serine protease TMPRSS2, which cleaves the viral spike protein in $\mathrm{S} 1 / \mathrm{S} 2$ allowing the fusion of viral and cell membranes (Hoffmann et al., 2020). In a study investigating the in vitro and in vivo translation and budding process of SARS-CoV-1 and MERS viruses, the infection caused by SARS-CoV-1 can be detected by various intercellular sensors (e.g., RIG I/MDA5/MAVS/TRAF3/IRF3/IRF7) and pathways (e.g., TLRs/TRIF/MyD88/IkB/NF-kB/MAPK/AP-1). Thus, the blocking of the IRF3 and RIG I pathways by the SARS virus produces the inhibition of the antiviral response and the inefficient production of type 1 interferons (Siu et al., 2009). As a result of all this process, cell death can lead to increased hyperinflation and cytokine storm.

IL-1 $\beta$ and IL-18, which cause exacerbation of symptoms of SARS-CoV-2 infection, are generated by NF- $\kappa \mathrm{B}$ pathway; these proinflammatory cytokines play a role in pathogenic inflammation and are activated through the detection of viral RNA using toll-like receptors (e.g., TLR-3, TLR7, TLR8 and TLR9) (Conti et al., 2020). Based on the report by Wang et al. (2020b), SARS-CoV-2 infects human T cell lines in a new way from the CD147 spike protein located on the surface of $\mathrm{T}$ lymphocytes.

The excess immune response caused by COVID-19, especially in the airway mucosa, can be suppressed by Treg cells (Loebbermann et al., 2013). While eosinophils, which contain and produce molecules with antiviral activity, serve as antigenpresenting cells as demonstrated in vitro and in vivo against some respiratory viruses, including respiratory syncytial virus and influenza (FloresTorres et al., 2019). 
The vast majority of patients with COVID-19 survive the disease without symptoms, while some of them with mild to moderate symptoms recover within a week (Dong et al., 2020; Huang et al., 2020). Nonetheless, some patients develop severe pneumonia in the second week, followed by excessive cytokine storm, acute respiratory distress syndrome, multiple organ dysfunction disorder, and disseminated intravascular coagulation in the third week (Azkur et al., 2020). Referring to the cytokine storm, it is a process characterized by the activation of large numbers of white blood cells, such as monocytes, neutrophils, macrophages, and NK, B and $\mathrm{T}$ cells, as well as the release of great amounts of proinflammatory cytokines (Behrens \& Koretzky, 2017; Zinovkin \& Grebenchikov, 2020). Among the causes of cytokine storm, cases such as Ebola, bacterial sepsis and other hemorrhagic fevers could be tied to some infectious and non-communicable diseases (e.g., flu and blunt trauma) (Liu et al., 2016; Channappanavar \& Perlman, 2017; Younan et al., 2017).

According to Lo Muzio et al. (2020), reported that natural purified polyphenols prevented pneumonitis caused by coronavirus. In another study conducted by Marinella (2020), showed that two potential anti-inflammatory agents include indomethacin, which has been shown in experimental models to decrease canine coronavirus levels in dogs and exhibit antiviral activity against several other viruses and the polyphenol, resveratrol, a potent antioxidant that has shown antiviral activity against several viruses.

According to Dennis and Norris (2015), the proinflammatory cytokines and eicosanoids play a key role in the inflammatory process caused by SARS-CoV-2, in the same way as TNF- $\alpha$, IL-6, IL12, IL-17, IL-1 $\beta$, and IFN- $\gamma$ (Chousterman et al., 2017). Meanwhile, IL-10 limits the expansion of tissue lesions in experimental models (Savarin \& Bergmann, 2018; Ashrafizadeh et al., 2020). Considering as described by Huang et al. (2005), high levels of monokine were detected in the serum of patients with SARS in the acute phase, and these monokines are induced by IL-6, IL-8, IL-18, interferon- $\gamma$-inducible protein-10 (CXCL10 or IP-10), monocyte chemoattractant protein-1 (MCP-1), IFN- $\gamma$, and TGF- $\beta$ (Huang et al., 2005; Savarin \& Bergmann, 2018).

Another important feature of asthma is airway hyperresponsiveness (AHR), and it was evaluated by Parlar and Arslan using unrestrained whole-body plethysmography, which is a method that can detect breathing patterns (Parlar \& Arslan, 2020). Furthermore, in human studies, SARS is known to cause acute inflammatory lung injury, characterized by bilateral alveolar opacities and decreased pulmonary compliance with acute hypoxemic respiratory failure on chest X-ray (Peiris et al., 2003; Fan et al., 2018). ARDS develops in patients within 3 weeks after SARS infection, whereas ARDS progresses in COVID-19 patients between 8-9 days after disease onset (Huang et al., 2020). Reports show that some diseases and factors such as bronchitis, diabetes, Parkinson's disease, ischemic disease of the central nervous system, hypertension, and coronary artery disease increase the severity of ARDS caused by SARS-CoV-2 and even cause the death of patients (Wujtewicz et al., 2020).

Since some herbal medicines suppress type 2 inflammation (Lee et al., 2018), resveratrol can lead to the beneficial effect of secondary restoration of impaired antiviral immunity in the exacerbation related to SARS-CoV-2 (Lin et al., 2017; Filardo et al., 2020). Thus, Lin et al. (2017) demonstrated that resveratrol is a potent anti-Middle East Respiratory Syndrome coronavirus (MERS-CoV) agent in vitro by down-regulating the apoptosis induced by MERS$\mathrm{CoV}$ and decreasing the expression of nucleocapsid (N) protein essential for MERS-CoV replication (Lin et al., 2017). Other research carried out on Vero E6 cell culture showed that the derived stilbene protects against SARS-CoV-induced cytopathy ( $\mathrm{Li}$ et al., 2006). In addition, Zhao et al. (2016), reported that resveratrol inhibited viral replication and mortality in ducklings infected with the duck enteritis virus. One more report by Zhao et al. (2017), always on the pseudorabies virus, which affects pigs causing fatal encephalitis and lung inflammation, evidenced that resveratrol inhibits intracellular viral proliferation by blocking the activity of I $\mathrm{B}$ kinase; this enzime is the key regulator in $\mathrm{NF}-\kappa \mathrm{B}$ activation. But despite the high antiviral potential of resveratrol, its oral bioavailability is low, which would constitute an apparent disadvantage. Nonetheless, Some researchers suggest that to improve its bioavailability, resveratrol can be combined in nanoparticle formulations or with modified beta-glucan in aqueous solutions (Baldassarre et al., 2020). In another example of reliability of the therapeutic effect of resveratrol against SARS-CoV-2, Cui et al. (2018), added resveratrol to the piglets' diet for 21 days, and they found that resveratrol reduced both TNF- $\alpha$ levels and diarrhea due to rotavirus. 
Besides all the health benefit effects listed above, resveratrol has adverse effects (Shaito et al., 2020). Some references have reported that resveratrol has hormetic effects, including pro-oxidant effects associated with high dose (Dai et al., 2007: Dei et al., 2009; Gadacha et al., 2009; Rocha et al., 2009; Guha et al., 2010; Posadino et al., 2019; Shaito et al., 2020). Moreover, resveratrol has been reported to have an immune toxic effect (Bolton \& Dunlap, 2017).

Recent studies have shown that some bioactive compounds found in dietary fruits could be active in suppressing SARS-CoV infection, among which resveratrol is found (Lin et al., 2017; Wang et al., 2020b).

\section{CONCLUSION}

This study shows that resveratrol would have the potential to reduce ARDS symptoms, both by suppressing the cytokine storm and severe inflammation caused by SARS-CoV-2, and by showing strong activity against various types of DNA and RNA viruses. Although the antiviral activity of resveratrol is known, the cell pathways leading to its protective activity in asthma have not yet been elucidated. Interestingly, some molecular pathways regulated by resveratrol, e.g., IFN- $\gamma$, TGF- $\beta$, NF- $\kappa$ B, TNF- $\alpha$, IL-6, IL-12, IL-17, or IL-1 $\beta$, also play an important role in the control of virus infection. Therefore, resveratrol can improve respiratory distress symptoms caused by covid-19 in patients with asthma.

\section{REFERENCES}

Abbas GM, Abdel Bar FM, Baraka HN, Gohar AA, Lahloub MF. 2014. A new antioxidant stilbene and other constituents from the stem bark of Morus nigra L. Nat Prod Res 28: 952 - 959.

https://doi.org/10.1080/14786419.2014.900770

Adesanya SA, Nia R, Martin MT, Boukamcha N, Montagnac A, Païs M. 1999. Stilbene derivatives from Cissus quadrangularis. J Nat Prod 62: 1694 - 1695. https://doi.org/10.1021/np9902744

Alhajj MS, Qasem MA, Al-Mufarrej SI. 2020. Inhibitory activity of Illicium verum extracts against avian viruses. Adv Virol 2020: https://doi.org/10.1155/2020/4594635

André DM, Calixto MC, Sollon C, Alexandre EC, Leiria LO, Tobar N, Anhê GF, Antunes E. 2016. Therapy with resveratrol attenuates obesity-associated allergic airway inflammation in mice. Int Immunopharmacol 38: 298 - 305. https://doi.org/10.1016/j.intimp.2016.06.017

Anjaneyulu ASR, Raghava Reddy AV, Reddy DSK, Ward RS, Adhikesavalu D, Stanley Cameron T. 1984. Pacharin: a new dibenzo(2,3-6,7)oxepin derivative from Bauhinia racemosa Lamk. Tetrahedron 40: 4245 - 4252. https://doi.org/10.1016/S0040-4020(01)98799-X

Aritomi M, Kiyota I, Linnaeus TM, Houttuyn RJ. 1965. Flavonoid constituents in leaves of Rumex acetosa. Chem Pharm Bull 13: 1470 - 1471. https://doi.org/10.1248/cpb.13.1470

Ashrafizadeh M, Najafi M, Orouei S, Zabolian A, Saleki H, Azami N, Sharifi N, Hushmandi K, Zarrabi A, Ahn KS. 2020. Resveratrol modulates transforming growth factor-beta (TGF- $\beta$ ) signaling pathway for disease therapy: A new insight into its pharmacological activities. Biomedicines 8: 261. https://doi.org/10.3390/biomedicines8080261

Azkur AK, Akdis M, Azkur D, Sokolowska M, van de Veen W, Brüggen MC, O’Mahony L, Gao Y, Nadeau K, Akdis CA. 2020. Immune response to SARS-CoV-2 and mechanisms of immunopathological changes in COVID-19. Allergy 75: 1464 - 1481. https://doi.org/10.1111/all.14364

Baldassarre ME, Di Mauro A, Labellarte G, Pignatelli M, Fanelli M, Schiavi E, Mastromarino P, Capozza M, Panza R, Laforgia N. 2020. Resveratrol plus carboxymethyl- $\beta$-glucan in infants with common cold: A randomized double-blind trial. Heliyon 6: e03814. https://doi.org/10.1016/j.heliyon.2020.e03814

Banach M, Penson PE, Fras Z, Vrablik M, Pella D, Reiner Ž, Nabavi SM, Sahebkar A, Kayikcioglu M, Daccord M. 2020. Brief recommendations on the management of adult patients with familial hypercholesterolemia during the COVID-19 pandemic. Pharmacol Res 2020: 104891. https://doi.org/10.1016/j.phrs.2020.104891

Behrens EM, Koretzky GA. 2017. Review: cytokine storm syndrome: looking toward the precision medicine era. Arthritis Rheumatol 69: 1135 - 1143. https://doi.org/10.1002/art.40071

Bolton JL, Dunlap T. 2017. Formation and biological targets of quinones: Cytotoxic versus cytoprotective effects. Chem Res Toxicol 30: 13 - 37. https://doi.org/10.1021/acs.chemrestox.6b00256

Borah HJ, Singhal R, Hazarika S. 2017. Artocarpus lakoocha Roxb.: An untapped bioresource of resveratrol from 
North East India, its extractive separation and antioxidant activity. Ind Crops Prod 95: 75 - 82. https://doi.org/10.1016/j.indcrop.2016.10.015

Borowska EJ, Mazur B, Kopciuch RG, Buszewski B. 2009. Polyphenol, anthocyanin and resveratrol mass fractions and antioxidant properties of cranberry cultivars. Food Technol Biotechnol 47: 56 - 61.

Carbó N, Costelli P, Baccino FM, López-Soriano FJ, Argilés JM. 1999. Resveratrol, a natural product present in wine, decreases tumour growth in a rat tumour model. Biochem Biophys Res Commun 254: 739 - 743. https://doi.org/10.1006/bbrc.1998.9916

Česoniene L, Daubaras R. 2015. Phytochemical composition of the large cranberry (Vaccinium macrocarpon) and the small cranberry (Vaccinium oxycoccos). In Nutritional composition of fruit cultivars. Elsevier Inc., The Netherland.

Channappanavar R, Perlman S. 2017. Pathogenic human coronavirus infections: causes and consequences of cytokine storm and immunopathology. Semin Immunopathol 39: 529 - 539. https://doi.org/10.1007/s00281-017-0629-x

Chang JC, Lai YH, Djoko B, Wu PL, Liu CD, Liu YW, Chiou RYY. 2006. Biosynthesis enhancement and antioxidant and anti-inflammatory activities of peanut (Arachis hypogaea L.) arachidin-1, arachidin-3, and isopentadienylresveratrol. J Agric Food Chem 54: 10281 - 10287. https://doi.org/10.1021/jf0620766

Chen L, Zhou Q, Li B, Liu SJ, Dong JX. 2015. A new flavonoid from Cudrania cochinchinensis. Nat Prod Res 29: 1217 - 1221. https://doi.org/10.1080/14786419.2014.997234

Chen X, Luo Y, Wang M, Sun L, Huang K, Li Y, Chen Y, Ding Y, Zhang X, Jiao L, Yang J, Huang T. 2019. Wuhu decoction regulates dendritic cell autophagy in the treatment of respiratory syncytial virus (RSV)-induced mouse asthma by AMPK/ULK1 signaling pathway. Med Sci Monit 25: 5389 - 5400. https://doi.org/10.12659/MSM.917692

Choi SW, Jang YJ, Lee YJ, Leem HH, Kim EO. 2013. Analysis of functional constituents in mulberry (Morus alba L.) twigs by different cultivars, producing areas, and heat processings. Prev Nutr Food Sci 18: 256 - 262. https://doi.org/10.3746/pnf.2013.18.4.256

Chousterman BG, Swirski FK, Weber GF. 2017. Cytokine storm and sepsis disease pathogenesis. Semin Immunopathol 39: 517 - 528. https://doi.org/10.1007/s00281-017-0639-8

Cui Q, Fu Q, Zhao X, Song X, Yu J, Yang Y, Sun K, Bai L, Tian Y, Chen S, Jia R, Zou Y, Li L, Liang X, He C, Yin L, Ye G, Lv C, Yue G, Yin Z, 2018. Protective effects and immunomodulation on piglets infected with rotavirus following resveratrol supplementation. PLoS One 13: e0192692.

https://doi.org/10.1371/journal.pone.0192692

Chukwumah YC, Walker LT, Verghese M, Ogutu S. 2009. Effect of frequency and duration of ultrasonication on the extraction efficiency of selected isoflavones and trans-resveratrol from peanuts (Arachis hypogaea). Ultrason Sonochem 16: 293 - 299. https://doi.org/10.1016/j.ultsonch.2008.07.007

Conti P, Ronconi G, Caraffa A, Gallenga CE, Ross R, Frydas I, Kritas SK. 2020. Induction of pro-inflammatory cytokines (IL-1 and IL-6) and lung inflammation by COVID-19: anti-inflammatory strategies. J Biol Regul Homeost Agents 2020: 34.

Contoli M, Message SD, Laza-Stanca V, Edwards MR, Wark PAB, Bartlett NW, Kebadze T, Mallia P, Stanciu LA, Parker HL, Slater L, Lewis-Antes L, Kon OM, Holgate ST, Davies DE, Kotenko SV, Papi A, Johnston SL. 2006. Role of deficient type III interferon- $\lambda$ production in asthma exacerbations. Nat Med 12: 1023 - 1026. https://doi.org/10.1038/nm1462

Contoli M, Ito K, Padovani A, Poletti D, Marku B, Edwards MR, Stanciu LA, Gnesini G, Pastore A, Spanevello A, Morelli P, Johnston SL, Caramori G, Papi A. 2015. Th2 cytokines impair innate immune responses to rhinovirus in respiratory epithelial cells. Allergy Eur J Allergy Clin Immunol 70: 910 - 920.

https://doi.org/10.1111/all.12627

Cunningham AC, Goh HP, Koh D. 2020. Treatment of COVID-19: Old tricks for new challenges. Crit Care 2020: 24. https://doi.org/10.1186/s13054-020-2818-6

D’Amato G, Vitale C, Molino A, Stanziola A, Sanduzzi A, Vatrella A, Mormile M, Lanza M, Calabrese G, Antonicelli L, D’Amato M. 2016. Asthma-related deaths. Multidiscip Respir Med 11: 1 - 5.

https://doi.org/10.1186/s40248-016-0073-0

Da Silva LMR, De Figueiredo EAT, Ricardo NMPS, Vieira IGP, De Figueiredo RW, Brasil IM, Gomes CL. 2014. Quantification of bioactive compounds in pulps and by-products of tropical fruits from Brazil. Food Chem 
143: 398 - 404. https://doi.org/10.1016/j.foodchem.2013.08.001

Dai Z, Li Y, Quarles LD, Song T, Pan W, Zhou H, Xiao Z. 2007. Resveratrol enhances proliferation and osteoblastic differentiation in human mesenchymal stem cells via ER-dependent ERK1/2 activation. Phytomedicine 14: 806 - 814. https://doi.org/10.1016/j.phymed.2007.04.003

Dennis EA, Norris PC. 2015. Eicosanoid storm in infection and inflammation. Nat Rev Immunol 15: 511 - 523. https://doi.org/10.1038/nri3859

Dey A, Guha P, Chattopadhyay S, Bandyopadhyay SK. 2009. Biphasic activity of resveratrol on indomethacininduced gastric ulcers. Biochem Biophys Res Commun 381: 90 - 95. https://doi.org/10.1016/j.bbrc.2009.02.027

Docherty JJ, Sweet TJ, Bailey E, Faith SA, Booth T. 2006. Resveratrol inhibition of varicella-zoster virus replication in vitro. Antiviral Res 72: 171 - 177. https://doi.org/10.1016/j.antiviral.2006.07.004

Dong X, Cao YY, Lu XX, Zhang JJ, Du H, Yan YQ, Akdis CA, Gao YD. 2020. Eleven faces of coronavirus disease 2019. Allergy 75: 1699 - 1709. https://doi.org/10.1111/all.14289

Duerr CU, Mccarthy CDA, Mindt BC, Rubio M, Meli AP, Pothlichet J, Eva MM, Gauchat JF, Qureshi ST, Mazer BD, Mossman KL, Malo D, Gamero AM, Vidal SM, King IL, Sarfati M, Fritz JH. 2016. Type I interferon restricts type 2 immunopathology through the regulation of group 2 innate lymphoid cells. Nat Immunol 17: 65 - 75. https://doi.org/10.1038/ni.3308

Ehala S, Vaher M, Kaljurand M. 2005. Characterization of phenolic profiles of Northern European berries by capillary electrophoresis and determination of their antioxidant activity. J Agric Food Chem 53: 6484 6490. https://doi.org/10.1021/jf050397w

Faith SA, Sweet TJ, Bailey E, Booth T, Docherty JJ. 2006. Resveratrol suppresses nuclear factor- $\kappa \mathrm{B}$ in herpes simplex virus infected cells. Antiviral Res 72: 242 - 251. https://doi.org/10.1016/j.antiviral.2006.06.011

Fan E, Brodie D, Slutsky AS. 2018. Acute respiratory distress syndrome advances in diagnosis and treatment. JAMA 319: 698 - 710. https://doi.org/10.1001/jama.2017.21907

Fan Y, Zhang Z, Yao C, Bai J, Yang H, Ma P, Fan Y, Li S, Yuan J, Lin M, Hou Q. 2019. Amurensin H, a derivative from resveratrol, ameliorates lipopolysaccharide/cigarette smoke-induced airway inflammation by blocking the Syk/NF- $\kappa$ B pathway. Front Pharmacol 10: https://doi.org/10.3389/fphar.2019.01157

Fanta CH. 2009. Asthma. N Engl J Med 360: 1002 - 1014. https://doi.org/10.1056/NEJMra0804579

Fei J, Fu L, Li Y, Xiang HX, Xiang Y, Li MD, Liu FF, Xu DX, Zhao H. 2020. Reduction of lymphocyte count at early stage elevates severity and death risk of COVID-19 patients: a hospital-based case-cohort study. Arch Med Sci 16: https://doi.org/10.5114/aoms.2020.99006

Filardo S, Di Pietro M, Mastromarino P, Sessa R. 2020. Therapeutic potential of resveratrol against emerging respiratory viral infections. Pharmacol Ther 214: 107613.

https://doi.org/10.1016/j.pharmthera.2020.107613

Flores-Torres AS, Salinas-Carmona MC, Salinas E, Rosas-Taraco AG. 2019. Eosinophils - respiratory viruses. Viral Immunol 32: 198 - 207. https://doi.org/10.1089/vim.2018.0150

Frémont L, Belguendouz L, Delpal S. 1999. Antioxidant activity of resveratrol and alcohol-free wine polyphenols related to LDL oxidation and polyunsaturated fatty acids. Life Sci 64: 2511 - 2521. https://doi.org/10.1016/S0024-3205(99)00209-X

Gadacha W, Ben-Attia M, Bonnefont-Rousselot D, Aouani E, Ghanem-Boughanmi N, Touitou Y. 2009. Resveratrol opposite effects on rat tissue lipoperoxidation: Pro-oxidant during day-time and antioxidant at night. Redox Rep 14: 154 - 158. https://doi.org/10.1179/135100009X466131

Gadani B, Bucci D, Spinaci M, Tamanini C, Galeati G. 2017. Resveratrol and epigallocatechin-3-gallate addition to thawed boar sperm improves in vitro fertilization. Theriogenology 90: 88 - 93. https://doi.org/10.1016/j.theriogenology.2016.11.020

Guha P, Dey A, Chatterjee A, Chattopadhyay S, Bandyopadhyay S. 2010. Pro-ulcer effects of resveratrol in mice with indomethacin-induced gastric ulcers are reversed by l-arginine. Br J Pharmacol 159: 726 - 734. https://doi.org/10.1111/j.1476-5381.2009.00572.x

Guo H, Huang M, Yuan Q, Wei Y, Gao Y, Mao L, Gu L, Tan YW, Zhong Y, Liu D, Sun S. 2017. The important role of lipid raft-mediated attachment in the infection of cultured cells by coronavirus infectious bronchitis virus beaudette strain. PLoS One 12: https://doi.org/10.1371/journal.pone.0170123

Guo T, Fan Y, Chen M, Wu X, Zhang L, He T, Wang H, Wan J, Wang X, Lu Z. 2020. Cardiovascular implications 
of fatal outcomes of patients with coronavirus disease 2019 (COVID-19). JAMA Cardiol 2020: https://doi.org/10.1001/jamacardio.2020.1017

Guzmán L, Balada C, Flores G, Álvarez R, Knox M, Vinet R, Martínez JL. 2018. t-Resveratrol protects against acute high glucose damage in endothelial cells. Plant Foods Hum Nutr 73: 235 - 240. https://doi.org/10.1007/s11130-018-0683-0

Han M, Rajput C, Hershenson MB. 2019. Rhinovirus attributes that contribute to asthma development. Immunol Allergy Clin North Am 39: 345 - 359. https://doi.org/10.1016/j.iac.2019.03.004

Heredia A, Davis C, Redfield R. 2000. Synergistic inhibition of HIV-1 in activated and resting peripheral blood mononuclear cells, monocyte-derived macrophages, and selected drug-resistant isolates with nucleoside analogues combined with a natural product, resveratrol. J Acquir Immune Defic Syndr 25: 246 - 255. https://doi.org/10.1097/00126334-200011010-00006

Hesselmar B, Enelund AC, Eriksson B, Padyukov L, Hanson LÅ, Aberg N. 2012. The heterogeneity of asthma phenotypes in children and young adults. J Allergy 2012: 163089. https://doi.org/10.1155/2012/163089

Hillis WE, Inoue T. 1967. The polyphenols of Nothofagus species-II. The heartwood of Nothofagus fusca. Phytochemistry 6: 59 - 67. https://doi.org/10.1016/0031-9422(67)85008-8

Hodgson E. 2015. The effects of corticosteroids and nonsteroidal anti-inflammatory drugs, including aspirin, on coagulation. South African Fam Pract 57: 9 - 12.

Hoffmann M, Kleine-Weber H, Schroeder S, Krüger N, Herrler T, Erichsen S, Schiergens TS, Herrler G, Wu NH, Nitsche A, Müller MA, Drosten C, Pôhlmann S. 2020. SARS-CoV-2 cell entry depends on ACE2 and TMPRSS2 and is blocked by a clinically proven protease inhibitor. Cell 181: $271-280$. https://doi.org/10.1016/j.cell.2020.02.052

Hu X, Wang J, Xia Y, Simayi M, Ikramullah S, He Y, Cui S, Li S, Wushouer Q. 2016. Resveratrol induces cell cycle arrest and apoptosis in human eosinophils from asthmatic individuals. Mol Med Rep 14: 5231 5236. https://doi.org/10.3892/mmr.2016.5884

Huang KS, Wang YH, Li RL, Lin M. 2000. Five new stilbene dimers from the lianas of Gnetum hainanense. J Nat Prod 63: 86 - 89. https://doi.org/10.1021/np990382q

Huang KJ, Su IJ, Theron M, Wu YC, Lai SK, Liu CC, Lei HY. 2005. An interferon- $\gamma$-related cytokine storm in SARS patients. J Med Virol 75: 185 - 194. https://doi.org/10.1002/jmv.20255

Huang C, Wang Y, Li X, Ren L, Zhao J, Hu Y, Zhang L, Fan G, Xu J, Gu X, Cheng Z, Yu T, Xia J, Wei Y, Wu W, Xie X, Yin W, Li H, Liu M, Xiao Y, Gao H, Guo L, Xie J, Wang G, Jiang R, Gao Z, Jin Q, Wang J, Cao B. 2020. Clinical features of patients infected with 2019 novel coronavirus in Wuhan, China. Lancet 395: 497 - 506. https://doi.org/10.1016/S0140-6736(20)30183-5

Huber JP, Ramos HJ, Gill MA, Farrar JD. 2010. Cutting edge: Type I IFN reverses human Th2 commitment and stability by suppressing GATA3. J Immunol 185: 813 - 817. https://doi.org/10.4049/jimmunol.1000469

Irnidayanti Y, Sutiono DR. 2019. Tempeh \& soybean seed coat: The alternative sources of trans-resveratrol as neuroprotective agents. Int J Morphol 37: 1164 - 1171. https://doi.org/10.4067/S0717-95022019000301164

Ito T, Tanaka T, Iinuma M, Iliya I, Nakaya KI, Ali Z, Takahashi Y, Sawa R, Shirataki Y, Murata J, Darnaedi D. 2003. New resveratrol oligomers in the stem bark of Vatica pauciflora. Tetrahedron 59: 5347 - 5363. https://doi.org/10.1016/S0040-4020(03)00730-0

Jackowska T, Wrotek A, Jankowski M, Pinkas J. 2020. Significant COVID-19 burden in Polish children. Arch Med Sci 16: https://doi.org/10.5114/aoms.2020.98407

James AL, Bai TR, Mauad T, Abramson MJ, Dolhnikoff M, McKay KO, Maxwell PS, Elliot JG, Green FH. 2009. Airway smooth muscle thickness in asthma is related to severity but not duration of asthma. Eur Respir J 34: 1040 - 1045. https://doi.org/10.1183/09031936.00181608

Jang M, Cai L, Udeani GO, Slowing KV, Thomas CF, Beecher CWW, Fong HHS, Farnsworth NR, Kinghorn AD, Mehta RG, Moon RC, Pezzuto JM. 1997. Cancer chemopreventive activity of resveratrol, a natural product derived from grapes. Science 275: 218 - 220. https://doi.org/10.1126/science.275.5297.218

Janssen LJ, Killian K. 2006. Airway smooth muscle as a target of asthma therapy: History and new directions. Respir Res 7: 1 - 12. https://doi.org/10.1186/1465-9921-7-123

Ji M, Li Q, Ji H, Lou H. 2014. Investigation of the distribution and season regularity of resveratrol in Vitis amurensis via hplc-dad-ms/ms. Food Chem 142: 61 - 65.

Boletín Latinoamericano y del Caribe de Plantas Medicinales y Aromáticas / 476 
https://doi.org/10.1016/j.foodchem.2013.06.131

Jiang H, Duan J, Xu K, Zhang W. 2019. Resveratrol protects against asthma-induced airway inflammation and remodeling by inhibiting the HMGB1/TLR4/NF- $\kappa B$ pathway. Exp Ther Med 18: https://doi.org/10.3892/etm.2019.7594

Johnston SL, Pattemore PK, Sanderson G, Smith S, Lampe F, Josephs L, Symington P, Toole SO, Myint SH, Tyrrell DAJ, Holgated ST. 1995. Community study of role of viral infections in exacerbations of asthma in 9-11 year old children. BMJ 310: 1225. https://doi.org/10.1136/bmj.310.6989.1225

Kim HJ, Chang EJ, Cho SH, Chung SK, Park HD, Choi SW. 2002. Antioxidative activity of resveratrol and its derivatives isolated from seeds of Paeoni. Biosci Biotechnol Biochem 66: 1990 - 1993. https://doi.org/10.1271/bbb.66.1990

Kim IH, Umezawa M, Kawahara N, Goda Y. 2007. The constituents of the roots of Ampelopsis japonica. J Nat Med 61: 224 - 225. https://doi.org/10.1007/s11418-006-0119-2

Kim JS. 2018. Antioxidant activities of selected berries and their free, esterified, and insoluble-bound phenolic acid contents. Prev Nutr Food Sci 23: 35 - 45. https://doi.org/10.3746/pnf.2018.23.1.35

Kim YI, Kim SG, Kim SM, Kim EH, Park SJ, Yu KM, Chang JH, Kim EJ, Lee S, Casel MAB, Um J, Song MS, Jeong HW, Lai VD, Kim Y, Chin BS, Park JS, Chung KH, Foo SS, Poo H, Mo IP, Lee OJ, Webby RJ, Jung JU, Choi YK. 2020. Infection and rapid transmission of SARS-CoV-2 in ferrets. Cell Host Microbe 27: 704 - 709. https://doi.org/10.1016/j.chom.2020.03.023

Kineman BD, Brummer EC, Paiva NL, Birt DF. 2010. Resveratrol from transgenic alfalfa for prevention of aberrant crypt foci in mice. Nutr Cancer 62: 351 - 361. https://doi.org/10.1080/01635580903407213

Krishnan V, Zeichner SL. 2004. Host cell gene expression during human immunodeficiency virus type 1 latency and reactivation and effects of targeting genes that are differentially expressed in viral latency. $\mathbf{J}$ Virol 78: 9458 - 9473. https://doi.org/10.1128/jvi.78.17.9458-9473.2004

Kudo M, Ishigatsubo Y, Aoki I. 2013. Pathology of asthma. Front Microbiol 4: 1 - 16. https://doi.org/10.3389/fmicb.2013.00263

Kumar K, Hinks TS, Singanayagam A. 2020. Treatment of COVID-19 exacerbated asthma: should systemic corticosteroids be used? Am J Physiol Cell Mol Physiol 2020: 00144. https://doi.org/10.1152/ajplung.00144.2020

Lam M, Royce SG, Samuel CS, Bourke JE. 2018. Serelaxin as a novel therapeutic opposing fibrosis and contraction in lung diseases. Pharmacol Ther 187: 61 - 70. https://doi.org/10.1016/j.pharmthera.2018.02.004 ç

Lee MS, Cho SM, Lee MH, Lee EO, Kim SH, Lee HJ. 2016. Ethanol extract of Pinus koraiensis leaves containing lambertianic acid exerts anti-obesity and hypolipidemic effects by activating adenosine monophosphateactivated protein kinase (AMPK). BMC Complement Altern Med 16: 51. https://doi.org/10.1186/s12906-016-1031-2

Lee LW, Lin HJ, Huang ST. 2018. Management of IFN-beta-induced flu-like symptoms with Chinese herbal medicine in a patient with multiple sclerosis: A case report. Complement Ther Med 36: 123 - 128. https://doi.org/10.1016/j.ctim.2017.12.011

Lee JW, Min JH, Kim MG, Kim SM, Kwon OK, Oh TK, Lee JK, Kim TY, Lee SW, Choi S, Li WY, Ryu HW, Ahn KS, Oh SR. 2019. Pistacia weinmannifolia root exerts a protective role in ovalbumin-induced lung inflammation in a mouse allergic asthma model. Int J Mol Med 44: 2171 - 2180. https://doi.org/10.3892/ijmm.2019.4367

Li YQ, Li ZL, Zhao WJ, Wen RX, Meng QW, Zeng Y. 2006. Synthesis of stilbene derivatives with inhibition of SARS coronavirus replication. Eur J Med Chem 41: 1084 - 1089. https://doi.org/10.1016/j.ejmech.2006.03.024

Li L, Zhang H, Qiao Y. 2007. HPLC determination of astilbin and resveratrol in Smilax glabra Roxb. Chin J Pharmaceut Anal 27: 654 - 656.

Li TL, Spiteller D, Spencer JB. 2009. Identification of a pentaketide stilbene produced by a type III polyketide synthase from Pinus sylvestris and characterisation of free coenzyme A intermediates. ChemBioChem 10: 896 - 901. https://doi.org/10.1002/cbic.200800840

Liberati A, Altman DG, Tetzlaff J, Mulrow C, Gøtzsche PC, Ioannidis JPA, Clarke M, Devereaux PJ, Kleijnen J, Moher D. 2009. The PRISMA statement for reporting systematic reviews and meta-analyses of studies that 
evaluate healthcare interventions: explanation and elaboration. BMJ 339:

https://doi.org/10.1136/bmj.b2700

Lin SC, Ho CT, Chuo WH, Li S, Wang TT, Lin CC. 2017. Effective inhibition of MERS-CoV infection by resveratrol. BMC Infect Dis 17: 144. https://doi.org/10.1186/s12879-017-2253-8

Lins AP, Felicio JD, Braggio MM, Roque LC. 1991. A resveratrol dimer from Parthenocissus tricuspidata. Phytochemistry 30: 3144 - 3146. https://doi.org/10.1016/S0031-9422(00)98274-8

Liu HX, Lin WH, Yang JS. 2004. Oligomeric stilbenes from the root of Caragana stenophylla. Chem Pharm Bull 52: 1339 - 1341. https://doi.org/10.1248/cpb.52.1339

Liu Q, Zhou YH, Yang ZQ. 2016. The cytokine storm of severe influenza and development of immunomodulatory therapy. Cell Mol Immunol 13: 3 - 10. https://doi.org/10.1038/cmi.2015.74

Loebbermann J, Durant L, Thornton H, Johansson C, Openshaw PJ. 2013. Defective immunoregulation in RSV vaccineaugmented viral lung disease restored by selective chemoattraction of regulatory T cells. Proc Natl Acad Sci USA 110: 2987 - 2992. https://doi.org/10.1073/pnas.1217580110

Lo Muzio L, Bizzoca ME, Ravagnan G. 2020. New intriguing possibility for prevention of coronavirus pneumonitis: Natural purified polyphenols. Oral Dis 2020: https://doi.org/10.1111/odi.13518

Lu R, Zhao X, Li J, Niu P, Yang B, Wu H, Wang W, Song H, Huang B, Zhu N, Bi Y, Ma X, Zhan F, Wang L, Hu T, Zhou H, Hu Z, Zhou W, Zhao L, Chen J, Meng Y, Wang J, Lin Y, Yuan J, Xie Z, Ma J, Liu WJ, Wang D, Xu W, Holmes EC, Gao GF, Wu G, Chen W, Shi W, Tan W. 2020. Genomic characterisation and epidemiology of 2019 novel coronavirus: implications for virus origins and receptor binding. Lancet 395: 565 - 574. https://doi,org/10.1016/S0140-6736(20)30251-8

Lyons MM, Yu C, Toma RB, Cho SY, Reiboldt W, Lee J, Van Breemen RB. 2003. Resveratrol in raw and baked blueberries and bilberries. J Agric Food Chem 51: 5867 - 5870. https://doi.org/10.1021/jf034150f

Marinella MA. 2020. Indomethacin and resveratrol as potential treatment adjuncts for SARS-CoV-2/COVID-19. Int J Clin Pract 74: e13535. https://doi.org/10.1111/ijcp.13535

Martínez JL, Yumrutas O, Muñoz-Acevedo A, Jaimes L, Parlar A. 2020. Medicinal plants containing resveratrol. A mini review. Med Plant Commun 3: 53 - 59. https://doi.org/10.37360/mpc.20.3.3.11

McMichael TM, Currie DW, Clark S, Pogosjans S, Kay M, Schwartz NG, Lewis J, Baer A, Kawakami V, Lukoff MD, Ferro J, Brostrom-Smith C, Rea TD, Sayre MR, Riedo FX, Russell D, Hiatt B, Montgomery P, Rao AK, Chow EJ, Tobolowsky F, Hughes MJ, Bardossy AC, Oakley LP, Jacobs JR, Stone ND, Reddy SC, Jernigan JA, Honein MA, Clark TA, Duchin JS. 2020. Epidemiology of Covid-19 in a long-term care facility in King County, Washington. N Engl J Med 382: 2005 - 2011.

https://doi.org/10.1056/NEJMoa2005412

Muangthai P, Daengchat J, Congcharoen J. 2014. Evaluation on total phenolic compound content and resveratrol content in Thai YaDong. IOSR J Appl Chem 7: 43 - 49. https://doi.org/10.9790/5736-07624349

Muñoz H, García S, Ruiz A. 2020. Contribution to determining the antioxidant capacity of melatonin in orodispersible tablets - comparison with reference antioxidants. Arch Med Sci 16: 871 - 877. https://doi.org/10.5114/aoms.2020.94106

Ning Y, Sun J, Lv LN, Tu PF, Jiang Y. 2013. [Chemical constituents from seeds of Vigna umbellata]. Zhongguo Zhong Yao Za Zhi 38: 1938 - 1941.

Palamara AT, Nencioni L, Aquilano K, De Chiara G, Hernandez L, Cozzolino F, Ciriolo MR, Garaci E. 2005. Inhibition of influenza A virus replication by resveratrol. J Infect Dis 191: 1719 - 1729. https://doi.org/10.1086/429694

Parlar A, Arslan SO. 2019. Resveratrol normalizes the deterioration of smooth muscle contractility after intestinal ischemia and reperfusion in rats associated with an antioxidative effect and modulating tumor necrosis factor alpha activity. Ann Vasc Surg 61: 416 - 426. https://doi.org/10.1016/j.avsg.2019.06.027

Parlar A, Arslan S. 2020. CB2 Agonist (AM1241) improving effect on ovalbumin-induced asthma in rats. Iran J Pharm Res 19: 3 - 17. https://doi.org/10.22037/ijpr.2019.1101002

Peiris JSM, Chu CM, Cheng VCC, Chan KS, Hung IFN, Poon LLM, Law KI, Tang BSF, Hon TYW, Chan CS, Chan KH, Ng JCS, Zheng BJ, Ng WL, Lai RWM, Guan Y, Yuen KY, and members of the HKU/UCH SARS Study Group. 2003. Clinical progression and viral load in a community outbreak of coronavirusassociated SARS pneumonia: A prospective study. Lancet 361: 1767 - 1772.

https://doi.org/10.1016/S0140-6736(03)13412-5

Boletín Latinoamericano y del Caribe de Plantas Medicinales y Aromáticas / 478 
Pelaia G, Renda T, Gallelli L, Vatrella A, Busceti MT, Agati S, Caputi M, Cazzola M, Maselli R, Marsico SA. 2008. Molecular mechanisms underlying airway smooth muscle contraction and proliferation: Implications for asthma. Respir Med 102: 1173 - 1181. https://doi.org/10.1016/j.rmed.2008.02.020

Posadino AM, Giordo R, Cossu A, Nasrallah GK, Shaito A, Abou-Saleh H, Eid AH, Pintus G. 2019. Flavin oxidase-induced ros generation modulates pkc biphasic effect of resveratrol on endothelial cell survival. Biomolecules 9: 209. https://doi.org/10.3390/biom9060209

Pourhanifeh MH, Shafabakhsh R, Reiter RJ, Asemi Z. 2019. The effect of resveratrol on neurodegenerative disorders: possible protective actions against autophagy, apoptosis, inflammation and oxidative stress. Curr Pharm Des 25: 2178 - 2191. https://doi.org/10.2174/1381612825666190717110932

Powell RG, TePaske MR, Plattner RD, White JF, Clement SL. 1994. Isolation of resveratrol from Festuca versuta and evidence for the widespread occurrence of this stilbene in the poaceae. Phytochemistry 35: 335 - 338. https://doi.org/10.1016/S0031-9422(00)94759-9

Pritchard AL, Carroll ML, Burel JG, White OJ, Phipps S, Upham JW. 2012. Innate IFNs and plasmacytoid dendritic cells constrain Th2 cytokine responses to rhinovirus: A regulatory mechanism with relevance to asthma. J Immunol 188: 5898 - 5905. https://doi.org/10.4049/jimmunol.1103507

Rajkumari J, Dyavaiah M, Sudharshan SJ, Busi S. 2018. Evaluation of in vivo antioxidant potential of Syzygium jambos (L.) Alston and Terminalia citrina Roxb. towards oxidative stress response in Saccharomyces cerevisiae. J Food Sci Technol 55: 4432 - 4439. https://doi.org/10.1007/s13197-018-3355-z

Rajwa P, Przydacz M, Krajewski W, Kuffel B, Zapala P, Krzywon A, Cortez A, Dybowski B, Stamirowski R, Jarzemski M, Drobot RB, Stelmach P, Mlynarek K, Marcinek M, Przudzik M, Krawczyk W, Ryszawy J, Choragwicki D, Zapala L, Lipa M, Pozniak M, Janczak D, Słomian S, Łaszkiewicz J, Nowak M, Miszczyk M, Roslan M, Tkocz M, Zdrojowy R, Potyka A, Szydełko T, Drewa T, Jarzemski P, Radziszewski P, Slojewski M, Antoniewicz A, Paradysz A, Chlosta PL. 2020. Changing patterns of urologic emergency visits and admissions during the COVID-19 pandemic: a retrospective, multicenter, nationwide study. Arch Med Sci 16: https://doi.org/10.5114/aoms.2020.98364

Reiner Ž, Hatamipour M, Banach M, Pirro M, Al-Rasadi K, Jamialahmadi T, Radenkovic D, Montecucco F, Sahebkar A. 2020. Statins and the Covid-19 main protease: In silico evidence on direct interaction. Arch Med Sci 16: 490 - 496. https://doi.org/10.5114/aoms.2020.94655

Rimando AM, Barney DL. 2005. Resveratrol and naturally occurring analogues in vaccinium species. Proceed Acta Hort 680: 137 - 143.

Rocha KKR, Souza GA, Ebaid GX, Seiva FRF, Cataneo AC, Novelli ELB. 2009. Resveratrol toxicity: Effects on risk factors for atherosclerosis and hepatic oxidative stress in standard and high-fat diets. Food Chem Toxicol 47: 1362 - 1367. https://doi.org/10.1016/j.fct.2009.03.010

Sagar SM, Yance D, Wong RK. 2006. Natural health products that inhibit angiogenesis: A potential source for investigational new agents to treat cancer - Part 2. Curr Oncol 13: 14 - 26.

Sahebkar A, Serban C, Ursoniu S, Wong ND, Muntner P, Graham IM, Mikhailidis DP, Rizzo M, Rysz J, Sperling LS, Lip GYH, Banach M, Lipid and Blood Pressure Meta-analysis Collaboration (LBPMC) Group. 2015. Lack of efficacy of resveratrol on C-reactive protein and selected cardiovascular risk factors - Results from a systematic review and meta-analysis of randomized controlled trials. Int J Cardiol 189: 47 - 55. https://doi.org/10.1016/j.ijcard.2015.04.008

Sarker SD, Whiting P, Dinan L, Šik V, Rees HH. 1999. Identification and ecdysteroid antagonist activity of three resveratrol trimers (suffruticosols A, B and C) from Paeonia suffruticosa. Tetrahedron 55: 513 - 524. https://doi.org/10.1016/S0040-4020(98)01049-7

Sarzi-Puttini P, Giorgi V, Sirotti S, Marotto D, Ardizzone S, Rizzardini G, Antinori S, Galli M. 2020. COVID-19, cytokines and immunosuppression: what can we learn from severe acute respiratory syndrome? Clin Exp Rheumatol 38: 337 - 342.

Savarin C, Bergmann CC. 2018. Fine tuning the cytokine storm by IFN and IL-10 following neurotropic coronavirus encephalomyelitis. Front Immunol 9: 3022. https://doi.org/10.3389/fimmu.2018.03022

Shaito A, Posadino AM, Younes N, Hasan H, Halabi S, Alhababi D, Al-Mohannadi A, Abdel-Rahman WM, Eid AH, Nasrallah GK, Pintus G. 2020. Potential adverse effects of resveratrol: A literature review. Int J Mol Sci 21: 2084. https://doi.org/10.3390/ijms21062084

Shinagawa K, Kojima M. 2003. Mouse model of airway remodeling. Am J Respir Crit Care Med 168: 959 - 967. 
https://doi.org/10.1164/rccm.200210-11880C

Shu YL, Fuchino H, Kawahara N, Sekita S, Satake M. 2002. New phenolic constituents from Smilax bracteata. J Nat Prod 65: 262 - 266. https://doi.org/10.1021/np010338m

Singh P, Gupta E, Mishra N, Mishra P. 2020. Shikimic acid as intermediary model for the production of drugs effective against influenza virus. In Phytochemicals as lead compounds for new drug discovery. Elsevier, The Netherland.

Siu KL, Kok KH, Ng MHJ, Poon VKM, Yuen KY, Zheng BJ, Jin DY. 2009. Severe acute respiratory syndrome coronavirus $\mathrm{M}$ protein inhibits type $\mathrm{I}$ interferon production by impeding theformation of TRAF3·TANK·TBK1/IKKe complex. J Biol Chem 284: 16202 - 16209. https://doi.org/10.1074/jbc.M109.008227

Soural I, Vrchotová N, Tříska J, Balík J, Horník Š, Cuř́nová P, Sýkora J. 2015. Various extraction methods for obtaining stilbenes from grape cane of Vitis vinifera L. Molecules 20: 6093 - 6112. https://doi.org/10.3390/molecules20046093

South AM, Diz DI, Chappell MC. 2020. COVID-19, ACE2, and the cardiovascular consequences. Am J Physiol Heart Circ Physiol 318: H1084 - H1090. https://doi.org/10.1152/ajpheart.00217.2020

Stivala LA, Savio M, Carafoli F, Perucca P, Bianchi L, Maga G, Forti L, Pagnoni UM, Albini A, Prosperi E, Vannini V. 2001. Specific structural determinants are responsible for the antioxidant activity and the cell cycle effects of resveratrol. J Biol Chem 276: 22586 - 22594. https://doi.org/10.1074/jbc.M101846200

Suzuki K, Shimizu T, Kawabata J, Mizutani J. 1987. New 3,5,4'-trihydroxystilbene (Resveratrol) oligomers from Carex fedia nees var. miyabei (franchet) t. koyama (Cyperaceae). Agric Biol Chem 51: 1003 - 1008. https://doi.org/10.1080/00021369.1987.10868133

Syah YM, Achmad SA, Ghisalberti EL, Hakim EH, Iman MZN, Makmur L, Mujahiddin D. 2000. Andalasin A, a new stilbene dimer from Morus macroura. Fitoterapia 71: 630 - 635.

https://doi.org/10.1016/S0367-326X(00)00221-5

Takaoka MJ. 1940. Of the phenolic substances of white hellebore (Veratrum grandiflorum Loe. fil.). J Faculty Sci Hokkaido Imperial Univ 3: 1 - 16.

Tanaka T, Ohyama M, Morimoto K, Asai F, Iinuma M. 1998. A resveratrol dimer from Parthenocissus tricuspidata. Phytochemistry 48: 1241 - 1243. https://doi.org/10.1016/S0031-9422(97)00898-4

Tanaka T, Iliya I, Ito T, Furusawa M, Nakaya K, Iinuma M, Shirataki Y, Matsuura N, Ubukata M, Murata J, Simozono F, Hirai K. 2001. Stilbenoids in lianas of Gnetum parvifolium. Chem Pharm Bull 49: 858 - 862. https://doi.org/10.1248/cpb.49.858

Thiery F. 2020. Linked COVID-19 Data: Johns Hopkins University (JHU) and European Centre for Disease Prevention and Control (ECDC). https://doi.org/10.5281/ZENODO.3829033

Tian X, Chen S, Tang L, Tu P. 2008. Three new isoflavonoids from the aerial parts of Ammopiptanthus mongolicus. Helv Chim Acta 91: 1015 - 1022. https://doi.org/10.1002/hlca.200890108

Tian B, Liu J. 2020. Resveratrol: a review of plant sources, synthesis, stability, modification and food application. J Sci Food Agric 100: 1392 - 1404. https://doi.org/10.1002/jsfa.10152

Wang LX, Heredia A, Song H, Zhang Z, Yu B, Davis C, Redfield R. 2004. Resveratrol glucuronides as the metabolites of resveratrol in humans: Characterization, synthesis, and anti-HIV activity. J Pharm Sci 93: 2448 - 2457. https://doi.org/10.1002/jps.20156

Wang P, Xu J, Wang Q, Feng SX, Chen T, Zhang CL. 2013. Phenylpropanoids and diphenylethene compounds from roots and rhizomes of Smilax scobinicaulis. Zhongguo Zhongyao Zazhi 38: 1531 - 1535.

Wang SC, Chen Y, Wang YC, Wang WJ, Yang CS, Tsai CL, Hou MH, Chen HF, Shen YC, Hung MC. 2020a. Tannic acid suppresses SARS-CoV-2 as a dual inhibitor of the viral main protease and the cellular TMPRSS2 protease. Am J Cancer Res 10: 4538-4546.

Wang X, Xu W, Hu G, Xia S, Sun Z, Liu Z, Xie Y, Zhang R, Jiang S, Lu L. 2020b. SARS-CoV-2 infects T lymphocytes through its spike protein-mediated membrane fusion. Cell Mol Immunol 17: 894.

https://doi.org/10.1038/s41423-020-0498-4

Wenzel SE. 2006. Asthma: defining of the persistent adult phenotypes. Lancet 368: 804 - 813. https://doi.org/10.1016/s0140-6736(06)69290-8

Worldometer Coronavirus Cases. 2021. Worldometer 2021: 1 - 22.

Wu Y, Li S, Liu J, Liu X, Ruan W, Lu J, Liu Y, Lawson T, Shimoni O, Lovejoy DB, Walker AK, Cong Y, Shi B. 
2018. Stilbenes from Veratrum maackii Regel protect against ethanol-induced DNA damage in mouse cerebellum and cerebral cortex. ACS Chem Neurosci 9: 1616 - 1624. https://doi.org/10.1021/acschemneuro.8b00006

Wujtewicz M, Dylczyk-Sommer A, Aszkiełowicz A, Zdanowski S, Piwowarczyk S, Owczuk R. 2020. COVID-19 what should anaethesiologists and intensivists know about it? Anaesthesiol Intensive Ther 52: 34 - 41. https://doi.org/10.5114/ait.2020.93756

Xiang W, Jiang B, Li XM, Zhang HJ, Zhao QS, Li SH, Sun HD. 2002. Constituents of Gnetum montanum. Fitoterapia 73: 40 - 42. https://doi.org/10.1016/S0367-326X(01)00370-7

Xu M, Deng Z, Li M, Li J, Fu H, Proksch P, Lin W. 2004. Chemical constituents from the mangrove plant, Aegiceras corniculatum. J Nat Prod 67: 762 - 766. https://doi.org/10.1021/np030477z

Younan P, Iampietro M, Nishida A, Ramanathan P, Santos RI, Dutta M, Lubaki NM, Koup RA, Katze MG, Bukreyev A. 2017. Ebola virus binding to Tim-1 on T lymphocytes induces a cytokine storm. MBio 8: https://doi.org/10.1128/mBio.00845-17

Yu G, Luo Z, Wang W, Li Y, Zhou Y, Shi Y. 2019. Rubus chingii Hu: A Review of the phytochemistry and pharmacology. Front Pharmacol 10: 799. https://doi.org/10.3389/fphar.2019.00799

Yuan S, Yin S, Liu M, Kong JQ. 2018. Isolation and characterization of a multifunctional flavonoid glycosyltransferase from Ornithogalum caudatum with glycosidase activity. Sci Rep 8: 1 - 13. https://doi.org/10.1038/s41598-018-24277-3

Zhai C, Li S, Feng W, Shi W, Wang J, Wang Q, Chai L, Zhang Q, Yan X, Li M. 2018. Association of interleukin17a rs2275913 gene polymorphism and asthma risk: A meta-analysis. Arch Med Sci 14: 1204 - 1211.

Zhang HS, Zhou Y, Wu MR, Zhou HS, Xu F. 2009. Resveratrol inhibited Tat-induced HIV-1 LTR transactivation via NAD+-dependent SIRT1 activity. Life Sci 85: 484 - 489. https://doi.org/10.1016/j.lfs.2009.07.014

Zhao W, Guo Y, Wang S, Shao T, Tezuka Y, Kikuchi T. 1998. [Chemical research on stilbenes from Veratrum macckii Reg]. China J Chin Materia Med 23:619 - 620.

Zhao X, Xu J, Song X, Jia R, Yin Z, Cheng A, Jia R, Zou Y, Li L, Yin L, Yue G, Lv C, Jing B. 2016. Antiviral effect of resveratrol in ducklings infected with virulent duck enteritis virus. Antiviral Res 130: 93 - 100. https://doi.org/10.1016/j.antiviral.2016.03.014

Zhao X, Cui Q, Fu Q, Song X, Jia R, Yang Y, Zou Y, Li L, He C, Liang X, Yin L, Lin J, Ye G, Shu G, Zhao L, Shi F, Lv C, Yin Z. 2017. Antiviral properties of resveratrol against pseudorabies virus are associated with the inhibition of IкB kinase activation. Sci Rep 7: https://doi.org/10.1038/s41598-017-09365-0

Zhou C, Tanaka J, Cheng C, Higa T, Tan R. 1999. Steroidal alkaloids and stilbenoids from Veratrum taliense. Planta Medica 65: 480 - 482. https://doi.org/10.1055/s-2006-960821

Zhu N, Zhang D, Wang W, Li X, Yang B, Song J, Zhao X, Huang B, Shi W, Lu R, Niu P, Zhan F, Ma X, Wang D, $\mathrm{Xu} \mathrm{W}$, Wu G, Gao GF, Tan W. 2020. A novel coronavirus from patients with pneumonia in China, 2019. N Engl J Med 382: 727 - 733. https://doi.org/10.1056/NEJMoa2001017

Zinovkin RA, Grebenchikov OA. 2020. Transcription factor Nrf2 as a potential therapeutic target for prevention of cytokine storm in COVID-19 patients. Biochemistry 85: 833 - 837.

https://doi.org/10.1134/S0006297920070111

Boletín Latinoamericano y del Caribe de Plantas Medicinales y Aromáticas / 481 